\title{
Humulus japonicus inhibits the progression of Alzheimer's disease in a APP/PS1 transgenic mouse model
}

\author{
TAE-SHIN PARK ${ }^{1,2^{*}}$, YOUNG-KYOUNG RYU ${ }^{1,3^{*}}$, HYE-YEON PARK ${ }^{1}$, JAE YUN KIM $^{1,4}$, JUN GO $^{1}$, \\ JUNG-RAN NOH ${ }^{1}$, YONG-HOON KIM ${ }^{1,4}$, JUNG HWAN HWANG ${ }^{1}$, DONG-HEE CHOI ${ }^{1}$, \\ WON-KEUN OH ${ }^{5}$, CHUL-HO LEE ${ }^{1,4}$ and KYOUNG-SHIM KIM ${ }^{1,4}$ \\ ${ }^{1}$ Laboratory Animal Resource Center, Korea Research Institute of Bioscience and Biotechnology (KRIBB), \\ Daejeon 305-806; ${ }^{2}$ College of Biosciences and Biotechnology, Chungnam National University, Daejeon 305-764; \\ ${ }^{3}$ Department of Toxicology Evaluation, Konyang University, Daejeon 302-832; ${ }^{4}$ Department of Functional Genomics, \\ University of Science and Technology (UST), Daejeon 305-350; ${ }^{5}$ Korea Bioactive Natural Material Bank, \\ Research Institute of Pharmaceutical Sciences, College of Pharmacy, \\ Seoul National University, Seoul 151-742, Republic of Korea
}

Received October 14, 2015; Accepted November 4, 2016

DOI: $10.3892 /$ ijmm.2016.2804

\begin{abstract}
Humulus japonicus Siebold \& Zucc. (HJ) has traditionally been administered to patients with pulmonary disease, skin disease and hypertension in Korea, and it is considered to exert anti-inflammatory, antioxidant, antimicrobial and antimycobacterial effects. However, its effects against Alzheimer's disease (AD) have yet to be explored. Thus, this study was carried out to investigate whether HJ has a beneficial effect on the progression of AD in an animal model. A methanolic extract of $\mathrm{HJ}(500 \mathrm{mg} / \mathrm{kg} /$ day) was intragastrically administered to 5-month-old APP/PS1 transgenic (Tg-APP/PS1) mice for 2.5 months. Novel object recognition and Y-maze alteration tests were used to assess cognitive function, and an immunohistochemical assay was performed to assess amyloid $\beta(\mathrm{A} \beta)$ deposition, tau phosphorylation and gliosis. An in vitro assay using a microglial cell line was also performed to investigate the anti-inflammatory effects of HJ. Our results revealed that HJ significantly decreased the mRNA and protein expression
\end{abstract}

Correspondence to: Dr Chul-Ho Lee or Dr Kyoung-Shim Kim, Laboratory Animal Resource Center, Korea Research Institute of Bioscience and Biotechnology (KRIBB), 125 Gwahak-ro, Yuseong-gu, Daejeon 305-806, Republic of Korea

E-mail: chullee@kribb.re.kr

E-mail: kskim@kribb.re.kr

${ }^{*}$ Contributed equally

Abbreviations: A $\beta$, amyloid $\beta ;$ AD, alzheimer's disease; ADAM10, a disintegrin and metalloproteinase 10; BACE1, beta-site APP-cleaving enzyme 1; IDE, insulin degrading enzyme; IL-1 $\beta$, interleukin-1 $\beta$; IL-6, interleukin-6; iNOS, inducible nitric oxide synthase; NEP, neprilysin; TNF- $\alpha$, tumor necrosis factor $\alpha$

Key words: Humulus japonicus, Alzheimer's disease, inflammation, cognition, $\beta$-amyloid plaque levels of tumor necrosis factor- $\alpha$ (TNF- $\alpha$ ), interleukin (IL)-1 $\beta$, IL-6 and inducible nitric oxide synthase (iNOS) induced by lipopolysaccharide in the microglial cell line. The administration of HJ for 2 months improved the cognitive function of Tg-APP/PS1 mice. HJ notably reduced the area occupied by $\mathrm{A} \beta$ and neurofibrillary tangles, and the number of activated astrocytes and microglia in the cortex of Tg-APP/PS1 mice. The findings of our study suggest that HJ has the therapeutic potential to inhibit the progression of $\mathrm{AD}$ and to improve cognitive deterioration in Tg-APP/PS1 mice.

\section{Introduction}

Alzheimer's disease (AD) is a progressive neurodegenerative disease characterized by the accumulation of senile plaques, the formation of neurofibrillary tangles, neuronal loss and progressive cognitive impairment. Amyloid $\beta(A \beta)$ aggregation and accumulation in the brain is considered a causative factor in the pathogenesis of $\mathrm{AD}$, while the progression of $\mathrm{AD}$ is considered to be multifactorial, and involves an increase in oxidative stress and inflammation (1-3). The increased accumulation of cellular reactive oxygen species (ROS) and oxidative damage to lipids, nucleic acids and proteins, as well as the activation of inflammatory responses are considered to play major roles in the process of age-related neurodegeneration and cognitive decline (3-7).

Many inflammatory pathways have been implicated in AD. Reactive glial cells, microglia and astrocytes produce multiple inflammatory factors, including cytokines, chemokines, ROS and cyclooxygenase-2 (COX-2). Elevated levels of these factors have been discovered in $\mathrm{AD}$ and are among the major mechanisms of AD neuropathology $(3,8)$. Anti-inflammatory drugs, such as non-steroidal anti-inflammatory drugs, peroxisome proliferator-activated receptor- $\gamma$ agonists, minocycline, and tumor necrosis factor- $\alpha$ (TNF- $\alpha$ ) inhibitors attenuate microglial activation, amyloid deposition and tau hyperphosphorylation in animal models of AD (9-14). Moreover, 
it has been demonstrated that several natural antioxidants and anti-inflammatory compounds, such as curcumin and grapederived polyphenols can inhibit $A \beta$ aggregation and attenuate cognitive deterioration (15-18).

Humulus japonicus Siebold \& Zucc. (HJ), also known as 'Japanese hop', is a perennial herb that belongs to the Cannabaceae family and is commonly distributed in Asian countries including Korea, Japan and China. In western countries, HJ was known to be originally imported for use as an ornamental vine, but it is now considered as an ecologically threatening plant due to the rapid growth and spreading capacity of the $\mathrm{HJ}$ vine, resulting in the blocking of light to plants beneath (19). According to previous studies, HJ has demonstrated scavenging effects on active oxygen molecules, such as superoxide radicals, hydroxyl radicals and hydrogen peroxide $(20,21)$. It has been reported that HJ exerts potent anti-inflammatory effects by blocking the generation of lipopolysaccharide (LPS)-induced TNF- $\alpha$, interleukin (IL)-1 $\beta$, IL-6, inducible nitric oxide synthase (iNOS) and COX-2 expression in the macrophage cell line, RAW264.7. Furthermore, HJ was found to inhibit the LPS-induced phosphorylation of the inhibitor of $\kappa \mathrm{B}-\alpha(\mathrm{I} \kappa \mathrm{B} \alpha)(22)$. However, the effects of HJ on AD have not yet been elucidated, at least to the best of our knowledge. In the present study, we investigated whether HJ confers a beneficial effect on glial-mediated inflammation in the central nervous system (CNS) and in APP/PS1 transgenic (Tg-APP/PS1) mice, a murine model of $\mathrm{AD}$, and demonstrated that $\mathrm{HJ}$ has a therapeutic potential to attenuate neuroinflammation, AD-like pathology and cognitive impairment.

\section{Materials and methods}

Animals. Tg-APPswe/PS1dE9 transgenic mice (Tg-APP/PS1 mice) were obtained from the Jackson Laboratory (Bar Harbor, ME, USA) and maintained in a hemizygote state by crossing transgenic C57BL6 x C3H F1 hybrid mice and non-transgenic C57BL6 x C3H F1 mice $(23,24)$. Mice not expressing the transgene were used as wild-type controls. The mice were housed in regular polycarbonate plastic cages in an environment with controlled temperature $\left(21-22^{\circ} \mathrm{C}\right)$ and humidity (50-60\%) with a 12-h light/dark cycle (lights on at 7 a.m.). Furthermore, the animals were maintained on an ad libitum diet of laboratory chow (2018S; Harlan Teklad, Madison, WI, USA) and had free access to water. The cages were filled to an approximate depth of $1.5 \mathrm{~cm}$ with bedding made of chopped wood particles (JSBio, Daejeon, Korea). All materials used were autoclaved and gamma-irradiated. The animal room was maintained under specific-pathogen-free (SPF) conditions. The Tg-APP/PS1 mice at 5 months of age were randomized into the control $(n=10)$ and $\mathrm{HJ}(\mathrm{n}=10)$ groups. The methanolic extract of $\mathrm{HJ}$ at $500 \mathrm{mg} / \mathrm{kg} /$ day or the vehicle were administered to the mice by oral gavage for 2.5 months from 5 months of age. All animal experiments were approved by the Institutional Animal Use and Care Committee of the Korea Research Institute of Bioscience and Biotechnology and were performed in accordance with the Guide for the Care and Use of Laboratory Animals published by the US National Institutes of Health (NIH publication, 8th edition, 2011).

Preparation and administration of HJ. HJ was purchased from Gangwon Herbs, Gangwon, Republic of Korea, on July, 2014.
The voucher specimen was identified by Professor W.K. Oh, and a voucher specimen (SNU-2014-0004) was deposited at the College of Pharmacy, Seoul National University, Korea. The HJ extract was then prepared and supplied by the Korea Bioactive Natural Material Bank (Seoul, Korea). Briefly, the dried aerial parts of HJ were soaked in $100 \%$ methanol in an extraction container for 2 days at room temperature. The methanol-soluble extract was filtered through a cheesecloth, concentrated exhaustively and dried to produce a methanolic extract under reduced pressure. This HJ extract was suspended in $0.5 \%$ carboxymethylcellulose (CMC) at a concentration of $50 \mathrm{mg} / \mathrm{ml}$ as a stock solution. The 5-month-old male and female mice were administered orally $500 \mathrm{mg} / \mathrm{kg} /$ day of HJ-methanol extract or $0.5 \% \mathrm{CMC}$ (vehicle) for 10 weeks.

Cell culture. BV-2 microglial cells (a gift from Dr B.S. Han, KRIBB, Daejeon, Korea) were maintained in Dulbecco's modified Eagle's medium (DMEM, Cat. no. SH30243.01; HyClone, Logan, UT, USA) supplemented with $10 \%$ heat-inactivated fetal bovine serum (FBS) and 1\% penicillin/streptomycin (both from Gibco, Grand Island, NY, USA). The cells were incubated at $37^{\circ} \mathrm{C}$ under $5 \% \mathrm{CO}_{2}$ and $95 \%$ relative humidity. They were seeded in 12-well plates ( $1 \times 10^{5}$ cells/well), incubated overnight, and thereafter co-treated with differently diluted HJ extracts (100 and $500 \mu \mathrm{g} / \mathrm{ml}$ ) for $24 \mathrm{~h}$. In this preliminary experiment, HJ concentrations of $50,100,200$ and $500 \mu \mathrm{g} / \mathrm{ml}$ were not shown to have cytotoxic effects on the BV-2 cells (data not shown). Subsequently, two different concentrations of $\mathrm{HJ}(100$ and $500 \mu \mathrm{g} / \mathrm{ml})$ were selected for use in further experiments, and the BV-2 cells were cultured under the same conditions with additional LPS $(1 \mu \mathrm{g} / \mathrm{ml}$, Sigma-Aldrich, St. Louis, MO, USA) for $24 \mathrm{~h}$.

Measurement of nitric oxide (NO) production. Nitrite in the culture supernatants was measured by the Griess reaction as an indicator of NO production. The BV2 cells were seeded in 12-well plates $\left(1 \times 10^{5}\right.$ cells/well), incubated overnight, and thereafter co-treated with various concentrations of HJ (100 and $500 \mu \mathrm{g} /$ $\mathrm{ml})$ and LPS $(1 \mu \mathrm{g} / \mathrm{ml})$ for $24 \mathrm{~h}$. Following LPS stimulation, a $100 \mu 1$ volume of culture supernatants from each sample were mixed with the same volume of Griess reagent (G4410; SigmaAldrich) and then incubated at room temperature for $15 \mathrm{~min}$. The NO concentration was determined by measuring the absorbance at $540 \mathrm{~nm}$ on a microplate reader (Thermo Multiskan Spectrum; Thermo Fisher Scientific, Waltham, MA, USA). The nitrite concentration was calculated with reference to a sodium nitrite standard curve generated with known concentrations.

Reverse transcription-quantitative polymerase chain reaction (RT-qPCR). RNA preparation and qPCR were performed as previously described (25). Following $24 \mathrm{~h}$ of stimulation with LPS or treatment with LPS $+\mathrm{HJ}$, the mRNA expression levels of TNF- $\alpha$, IL- $1 \beta$, IL- 6 , iNOS and $\beta$-actin in BV2 microglial cells were evaluated by RT-qPCR. In addition, following the administration of $\mathrm{HJ}$ for 2.5 months in vivo, mice were anesthetized with Avertin ( $0.3 \mathrm{~g} / \mathrm{kg}$, i.p.) and the mouse brain was extracted and dissected using Rodent Brain Matrix (ASI Instruments, Warren, MI, USA). The cortex was removed and the expression levels of TNF- $\alpha$, IL-1 $\beta$ and IL- 6 were evaluated by RT-qPCR. Total RNA was purified from the cells and tissues using TRI reagent (Sigma-Aldrich). Reverse 
transcription was carried out using a Promega RT-PCR kit (Promega, Madison, WI, USA). PCR reaction was prepared with a mix of $5 \mu \mathrm{l}$ of $2 \mathrm{X}$ SYBR-Green mix and performed using the StepOne Real-Time PCR system (both from Applied Biosystems, Foster City, CA, USA). The cycle number at which the fluorescence emission exceeds the fixed threshold was defined as threshold cycle (CT). The cycling conditions were as follows: $10 \mathrm{~min}$ at $95^{\circ} \mathrm{C}$, followed by 41 cycles of $20 \mathrm{sec}$ at $95^{\circ} \mathrm{C}, 30 \mathrm{sec}$ at $60^{\circ} \mathrm{C}$, and $20 \mathrm{sec}$ at $72^{\circ} \mathrm{C}$. The difference in amplification fold was calculated based on qPCR amplification of the target gene vs. $\beta$-actin as a reference using built-in software of the Gene Expression Analysis for StepOne Software version 2.1 (Applied Biosystems). qPCR was repeated 4 times. The following primer sets were used: TNF- $\alpha$ forward, $5^{\prime}$-ATCC GCGACGTGGAACTG-3' and reverse, 5'-ACCGCCTG GAGTTCTGGAA-3'; IL-1 $\beta$ forward, 5'-CTACAGGCT CCGAGATGAACAAC-3' and reverse, 5'-TCCATTGAGG TGGAGAGCTTTC-3'; IL-6 forward, 5'-TTCCATCCAGTT GCCTTCTTG-3' and reverse, 5'-GGGAGTGGTATCCTC TGTGAAGTC-3'; iNOS forward, 5'-GTTCTCAGCCCAA CAATACAAGA-3' and reverse, 5'-GTGGACGGGTCGAT GTCAC-3'; and $\beta$-actin forward, 5'-TATTGGCAACG AGCGGTTCC-3' and reverse, 5'-GGCATAGAGGTCT TTACGGATGT-3'.

Cytokine assays. The levels of TNF- $\alpha$, IL-1 $\beta$, and IL-6 produced were measured using ELISA kits (BD Biosciences, San Diego, CA, USA) according to the manufacturer's instructions. Briefly, the BV2 microglial cells were seeded in 12-well plates $\left(1 \times 10^{5}\right.$ cells/well $)$, incubated overnight and thereafter co-treated with various concentrations of $\mathrm{HJ}(100$ and $500 \mu \mathrm{g} /$ $\mathrm{ml})$ and LPS $(1 \mu \mathrm{g} / \mathrm{ml})$ for $24 \mathrm{~h}$. A total of $100 \mu \mathrm{l}$ of culture supernatants was collected to determine the TNF- $\alpha$, IL-1 $\beta$, and IL- 6 concentrations by ELISA.

Novel object recognition test. Novel object recognition is a validated and widely used test for assessing recognition memory $(26,27)$. The mice were placed individually in a $40 \times 20 \times 20 \mathrm{~cm}^{3}$ testing chamber for $10 \mathrm{~min}$ with two identical objects (familiar, acquisition session). The mice were then returned to home cages and one day they later placed back in the testing chamber in the presence of one of the original objects and one novel object (novel, recognition session) for $10 \mathrm{~min}$. The original objects were cylindrical wooden blocks $10 \mathrm{~cm}$ high $\mathrm{x} 2 \mathrm{~cm}$ in diameter. The novel object was a $10 \times 2.5 \times 2 \mathrm{~cm}$ rectangular wooden block. The acquisition and recognition sessions were video-recorded and an observer who was blinded to the drug treatment scored the time spent exploring the objects. The chambers and objects were cleaned with ethanol between trials. Exploration was defined as sniffing and touching the object with the nose and/or forepaws. Sitting on the object was not considered exploratory behavior. In preliminary experiments, wild-type mice exhibited no significant preference for the cylindrical or rectangular block. The time spent exploring both objects was calculated. A discrimination index was calculated for each animal and expressed by the ratio of time spent exploring the novel object - time spent exploring the familiar object/(time spent exploring the novel object + time spent exploring the familiar object) on day 2, as previously described (28).
Spontaneous $Y$-maze alternation test. The Y-maze test was conducted as previously described (29). A Y-maze with three identical arms of plexiglass $(51.5 \times 11.5 \times 12 \mathrm{~cm}) 120^{\circ}$ apart was placed in the center of a room. The walls of each arm had a distinct design that provided visual cues. Each mouse was placed at the end of one arm facing the center and allowed to explore the maze for a period of $10 \mathrm{~min}$. The sessions were video-recorded and scored for entries into arms. The percentage of spontaneous alternation was calculated as the ratio of the actual to possible alternations (defined as the total number of arm entries minus 2) multiplied by 100: alternation $(\%)=[($ number of alternation $) /($ total arm entries -2$)] \times 100$.

Immunohistochemistry. Immunohistochemistry was conducted as previously described (30). The mice were transcardially perfused with phosphate-buffered saline (PBS) followed by 4\% paraformaldehyde in PBS. The perfused brains were dissected, post-fixed overnight and then cut into $40-\mu \mathrm{m}$-thick coronal sections on a vibratome (Vibratome VT1000A; Leica, Mannheim, Germany). Free-floating sections were incubated in PBS containing $3 \% \mathrm{H}_{2} \mathrm{O}_{2}(\mathrm{v} / \mathrm{v})$, rinsed 3 times in PBS, and blocked with serum for $1 \mathrm{~h}$ at room temperature. The sections were incubated overnight at $4^{\circ} \mathrm{C}$ with the primary antibodies. The primary antibodies were mouse monoclonal antibodies against Bam10 (4\% BSA, Cat. no. A5213; Sigma-Aldrich), rabbit polyclonal antibodies against ionized calcium-binding adapter molecule 1 (Iba-1, 5\% HS, Cat. no. 019-19741; Wako, Richmond, VA, USA), glial fibrillary acidic protein (GFAP, 5\% GS, Cat. no. Z0334; Dako) and mouse polyclonal antibody against AT8 (phospho-tau, 5\% GS, Cat. no. MN1020; Thermo Fisher Scientific). Immunohistochemistry was then performed using biotinylated secondary anti-rabbit IgG, and avidin-biotinylated peroxidase complex (ABC kit) (both from Vector Laboratories, Burlingame, CA, USA), and 3,3'-diaminobenzidine (Sigma-Aldrich). Sections containing the parietal cortex were selected and the number of plaques in the cortex was counted under a microscope (Olympus Corp., Tokyo, Japan). The assessments of Bam10-stained areas in the cortex were performed using the MetaMorph image analyzer (Molecular Devices Inc., Sunnyvale, CA, USA).

Western blot analysis. Western blot analysis was performed as described in a previous study (25). The mice were sacrificed and the brain tissues were rapidly removed and homogenized in homogenization buffer (50 mM Tris- $\mathrm{HCl}, \mathrm{pH} 8.0,150 \mathrm{mM} \mathrm{NaCl}$, $1 \%$ Nonidet $\mathrm{P}-40,0.1 \%$ sodium dodecyl sulfate, and $0.1 \%$ sodium deoxycholate) containing a cocktail of protease inhibitors (Roche, Mannheim, Germany). Protein samples were resolved by performing sodium dodecyl sulfate-polyacrylamide gel electrophoresis, and were then transferred onto polyvinylidene fluoride membranes (Bio-Rad Laboratories, Inc., Hercules, CA, USA). The blots were incubated with primary antibodies followed by secondary antibodies, and specific signals were visualized using an enhanced chemiluminescence kit (Intron Biotechnology, Seoul, Korea). The western blot images were quantified using Quantity One 1-D analysis software version 4.6.1 (Bio-Rad Laboratories, Inc.). The primary antibodies were C-terminal fragments (CTFs, Cat.no. A8717; Sigma-Aldrich), phosphoamyloid precursor protein (p-Thr668 APP, Cat.no. 6986; Cell Signaling Technology, Inc., Danvers, MA, USA), a disintegrin 
and metalloproteinase 10 (ADAM10, Cat. no. AB1997) and beta-site APP-cleaving enzyme 1 (BACE1, Cat. no. AB2077) (both from Abcam, Cambridge, UK), neprilysin (NEP, Cat. no. SC-9149; Santa Cruz Biotechnology, Inc., Dallas, TX, USA), insulin degrading enzyme (IDE, Cat. no. 97-273; Calbiochem, Darmstadt, Germany), vesicular glutamate transporter 1 (vGlut1, Cat. no. 135 302; Synaptic Systems, Göttingen, Germany), N-methyl-D-aspartate receptor subtype 2B (NR2B, Cat. no. 06-600; Merck Millipore, Darmstadt, Germany), synaptophysin (SYP, Cat. no. S5768; Sigma-Aldrich), $\beta$-actin (Cat. no. MAB1501; Merck Millipore) and post-synaptic density protein 95 (PSD-95, a gift from Dr J.-R Lee; KRIBB). The secondary antibodies were goat anti-rabbit IgG (Cat. no. sc-2004; Santa Cruz Biotechnology, Inc.) and goat anti-mouse IgG (Cat. no. sc-2005; Santa Cruz Biotechnology, Inc.).

Statistical analysis. Two-sample comparisons were carried out using the Student's t-test, while multiple comparisons were made using one-way ANOVA followed by Tukey-Kramer's post hoc test. All data are presented as the means \pm SEM and statistical differences were accepted at the 5\% level $(p<0.05)$ unless otherwise indicated.

\section{Results}

HJ suppresses LPS-induced NO production by microglial cells. To examine the inhibitory effects of HJ on LPS-induced NO production by BV2 cells, the NO levels in the culture medium were measured by Griess reaction. Stimulation of the BV2 cells with LPS caused a marked induction of NO production. However, treatment with $\mathrm{HJ}$ resulted in the significant inhibition of LPS-induced NO production (Fig. 1A). We also performed RT-qPCR to determine whether the inhibition of NO production by HJ in the LPS-stimulated BV2 cells is associated with the decreased levels of iNOS, which produces $\mathrm{NO}$ as a key mediator of inflammation. Treatment with $\mathrm{HJ}$ resulted in a significant decrease in the mRNA expression of iNOS in the LPS-stimulated BV2 cells (Fig. 1B). These results indicated that the $\mathrm{HJ}$-induced decrease in the expression of iNOS is responsible for the inhibition of NO production.

$H J$ decreases the mRNA expression and the release of LPS-induced pro-inflammatory cytokines from microglial cells. In order to investigate whether $\mathrm{HJ}$ inhibits the expression of LPS-induced pro-inflammatory cytokines in the murine microglial cell line, BV2, the cells were co-treated with LPS and HJ for $24 \mathrm{~h}$ and the mRNA levels of TNF- $\alpha$, IL- $1 \beta$ and IL- 6 were then analyzed by RT-qPCR. As shown in Fig. 2A-C, the LPS-induced increase in the expression of TNF- $\alpha$, IL-1 $\beta$ and IL- 6 was significantly decreased by treatment with HJ. The production of TNF- $\alpha$, IL- $1 \beta$ and IL- 6 induced by LPS in the culture supernatants was evaluated by ELISA. The levels of TNF- $\alpha$, IL- $1 \beta$ and IL- 6 were significantly increased in the culture medium of LPS-stimulated BV2 cells; however, co-treatment with $\mathrm{HJ}$ resulted in a marked decrease in the release of these pro-inflammatory cytokines (Fig. 2D-F). These results suggest that $\mathrm{HJ}$ is effective in the suppression of pro-inflammatory cytokine production through the alteration of the transcript levels of TNF- $\alpha$, IL- $1 \beta$ and IL- 6 in activated BV2 microglial cells.
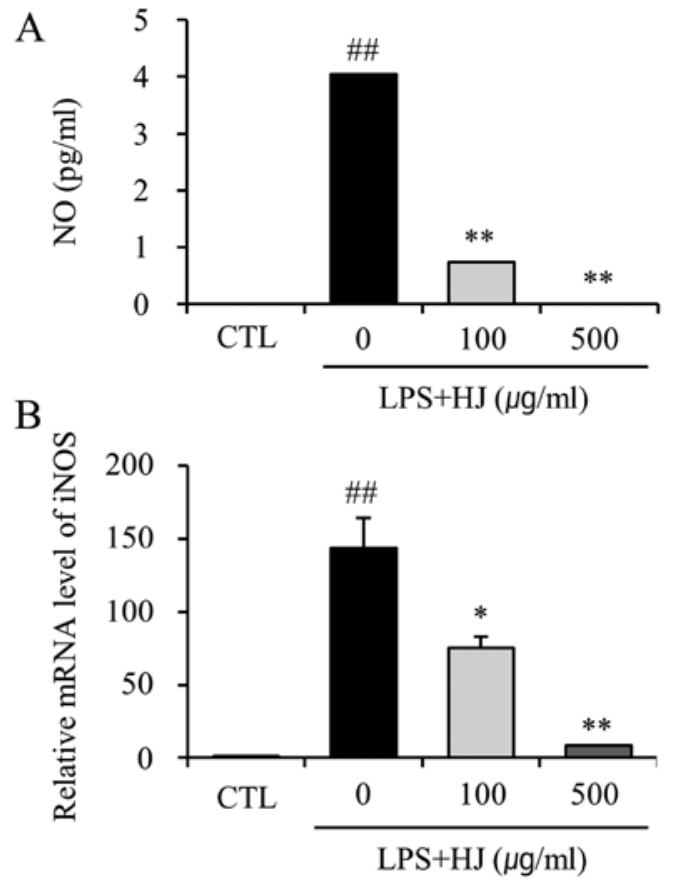

Figure 1. Effect of Humulus japonicus (HJ) on lipopolysaccharide (LPS)induced nitric oxide (NO) production by BV2 microglial cells. BV2 microglial cells were co-treated with 100 and $500 \mu \mathrm{g} / \mathrm{ml}$ concentrations of $\mathrm{HJ}$ with LPS $(1 \mu \mathrm{g} / \mathrm{ml})$. Following incubation for $24 \mathrm{~h}$, (A) NO production and (B) the mRNA level of inducible nitric oxide synthase (iNOS) were measured using the culture supernatants of BV2 cells and their lysates, respectively. ${ }^{*} \mathrm{p}<0.05$, and ${ }^{* *} \mathrm{p}<0.01$, significant differences from the LPS-treated group; ${ }^{\# \#} \mathrm{p}<0.01$, significant differences from the control group (CTL), as shown by the Student's t-test. Data are presented as the means \pm SEM.

HJ improves cognitive function in Tg-APP/PS1 mice. Based on the in vitro anti-inflammatory effects of $\mathrm{HJ}$, we examined whether $\mathrm{HJ}$ has a therapeutic effect on an animal model of AD. Tg-APP/PS1 mice were administered $\mathrm{HJ}$ at a dose of $500 \mathrm{mg} / \mathrm{kg} / \mathrm{day}$ for 2 months from 5 months of age. The body weight of the HJ group during the treatment period was similar to that of the controls (data not shown). To investigate whether the treatment of Tg-APP/PS1 mice with HJ functionally attenuates AD-type cognitive deterioration, we evaluated object recognition memory (27) and spatial working learning and memory (31) using the object recognition test and spontaneous Y-maze alteration test in $\mathrm{HJ}$ - or vehicle-treated mice. The HJ-treated Tg-APP/PS1 mice exhibited increased exploration preference of the novel object during the recognition session of the object recognition test compared with vehicle-treated Tg-control mice (Fig. 3A). In the spontaneous Y-maze alteration test, the HJ-treated Tg-APP/PS1 mice exhibited increased alteration percentage compared with the vehicle-treated Tg-control mice (Fig. 3B). This increase in the percentage of spontaneous alterations was statistically significant $(\mathrm{p}<0.05)$. These results indicated that treatment with $\mathrm{HJ}$ for 2 months improved the cognitive decline of Tg-APP/PS1 mice.

\section{$H J$ reduces the $A \beta$ level and tau phosphorylation in the brains} of Tg-APP/PSI mice. Subsequently, to investigate whether HJ can attenuate the levels of $A \beta$ and tau hyperphosphorylation in Tg-APP/PS1 mice, we measured the percentage area occupied by plaques and phospho-tau in the cortex by immunohisto- 
A

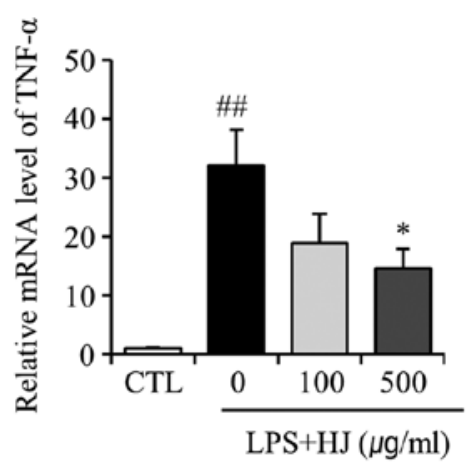

$\mathrm{D}$

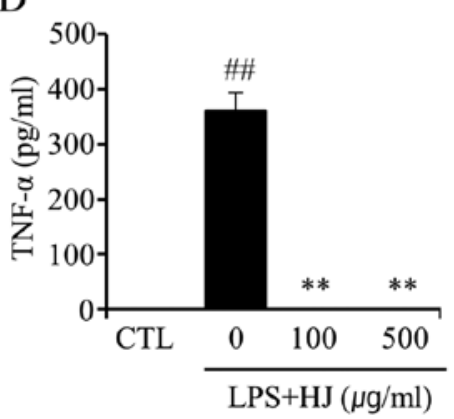

$\mathrm{B}$
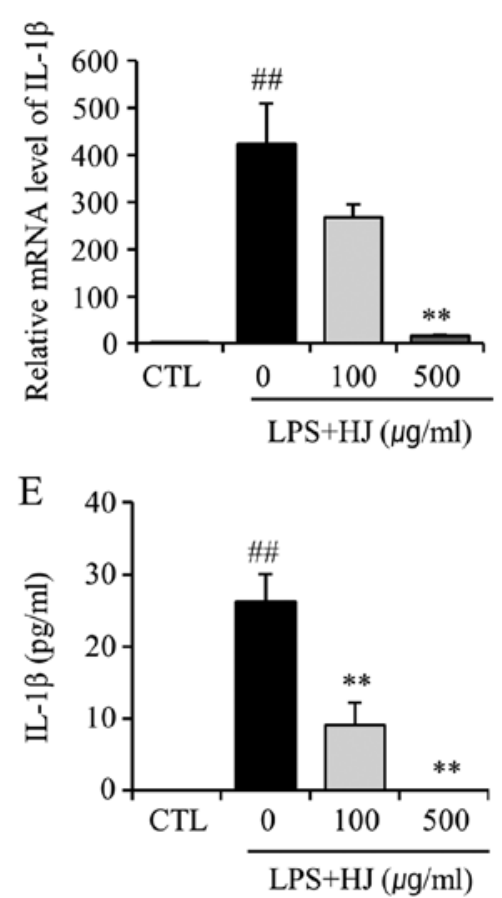

C
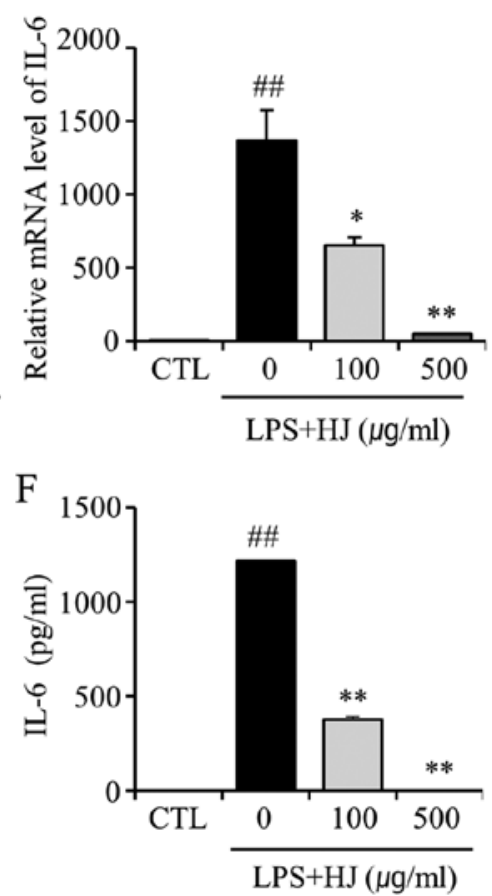

Figure 2. Effect of Humulus japonicus (HJ) on lipopolysaccharide (LPS)-induced tumor necrosis factor- $\alpha$ (TNF- $\alpha$ ), interleukin-1 $\beta$ (IL-1 $\beta$ ) and interleukin-6 (IL-6) production by BV2 microglial cells. BV2 cells were co-treated with various concentrations of $\mathrm{HJ}$ with LPS ( $1 \mu \mathrm{g} / \mathrm{ml})$. Following incubation for $24 \mathrm{~h}$, the mRNA levels of (A) TNF- $\alpha$, (B) IL-1 $\beta$ and (C) IL-6 were measured in BV2 microglial cell lysates. The production levels of (D) TNF- $\alpha$, (E) IL-1 $\beta$ and (F) IL-6 were measured using the culture supernatants. ${ }^{*} \mathrm{p}<0.05$, and ${ }^{* *} \mathrm{p}<0.01$, significant differences from LPS-treated group; ${ }^{\# \#} \mathrm{p}<0.01$, significant differences from control group (CTL), as shown by the Student's t-test. Data are presented as the means \pm SEM.
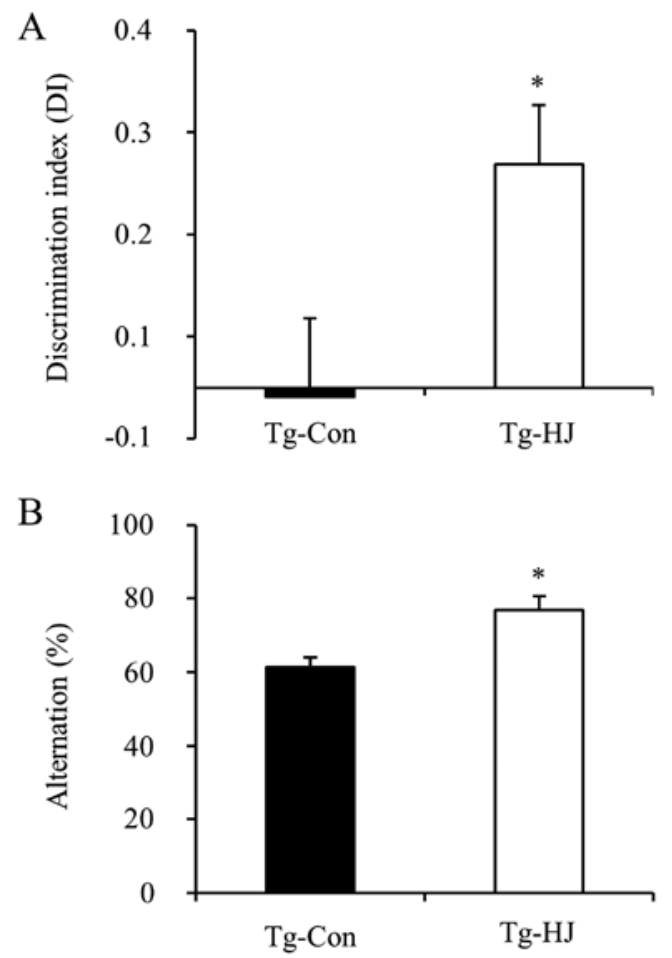

Figure 3. Enhanced novel-object recognition and spatial working memory in Humulus japonicus (HJ)-treated APP/PS1 transgenic (Tg-APP/PS1) mice. (A) HJ-treated Tg-APP/PS1 (Tg-HJ) mice and vehicle-treated Tg-control ( $\mathrm{Tg}$-Con) mice exhibited increased exploration preference of a novel object during recognition session of object recognition test. (B) HJ-treated Tg-APP/PS1 mice showed increased alteration percentage in the spontaneous Y-maze alteration test. ${ }^{*} \mathrm{p}<0.05$, significant differences from Tg-control, as shown by the Student's t-test. Data are presented as the means \pm SEM. chemical assay. The Tg-APP/PS1 mice were administered $\mathrm{HJ}$ at a dose of $500 \mathrm{mg} / \mathrm{kg} /$ day for 2.5 months from 5 months of age. The administration of $\mathrm{HJ}$ effectively decreased the percentage area occupied by amyloid plaques in the cortex (Fig. 4A-C; $\mathrm{p}<0.05)$. Tau hyperphosphorylation was also significantly decreased in the HJ-treated Tg-APP/PS1 mice compared with the vehicle-treated Tg-control mice (Fig. 4D-F; p<0.01).

$H J$ increases IDE protein expression for A $\beta$ clearance in the brains of Tg-APP/PS1 mice. In order to further investigate which factors contributed to the reduction of $A \beta$ in HJ-treated Tg-APP/PS1 mice, the changes in APP processing and $A \beta$ clearance-related factors were analyzed using brain tissues from both groups of mice. As shown by the results of western blot analysis, HJ had no effect on the protein expression of total APP (Fig. 5A and B), phospho-APP (Fig. 5A and $\mathrm{C}$ ), and the $\beta$-cleavage product $(\mathrm{CTF} \beta)$ and $\alpha$-cleavage product (CTF $\alpha$ ) (Fig. 5A, D and E). In addition, treatment with HJ did not alter the levels of ADAM10 ( $\alpha$-secretase) and BACE1 ( $\beta$-secretase) (Fig. 5A, F and G). Moreover, since the proteolytic degradation of $A \beta$ is known to be a major route for the clearance of plaques and neprilysin, and insulin degrading enzyme and major $A \beta$-degrading metalloproteases are involved in the downregulation of the levels of $A \beta$ secreted extracellularly $(32,33)$, the protein levels of NEP and IDE in brain tissues were determined in both groups. Immunoreactivity assessed by western blot analysis of IDE expression was significantly increased in the HJ-treated Tg-APP/PS1 mice (Fig. 5A and I), but the level of NEP was not altered (Fig. 5A and H). These 
A

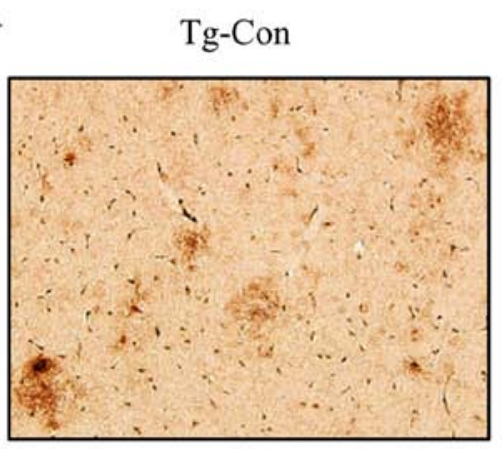

D

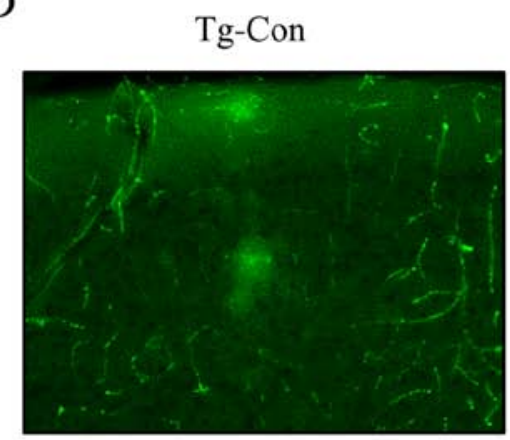

B

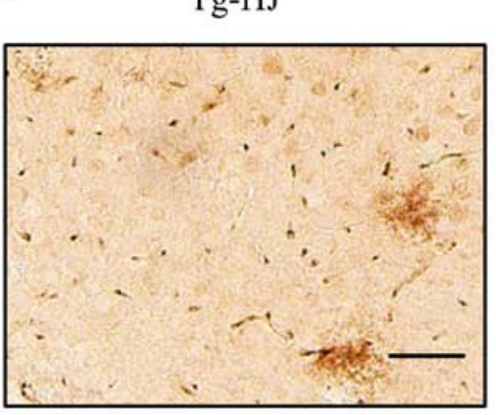

E

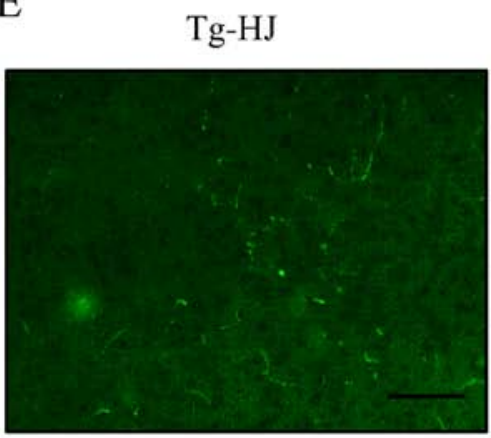

C

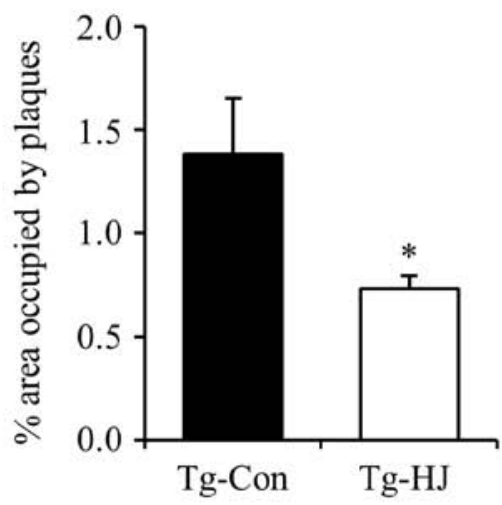

F

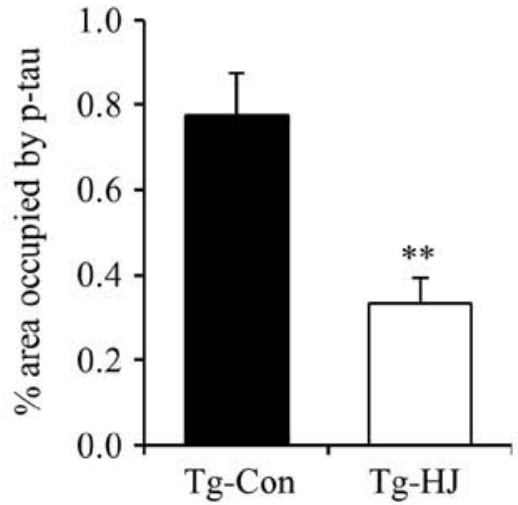

Figure 4. Effect of Humulus japonicus (HJ) on plaque deposition and tau phosphorylation in the brains of APP/PS1 transgenic (Tg-APP/PS1) mice. Photomicrographs showing anti-amyloid $\beta$ (A $\beta$ ) antibody (Bam10)-stained cortex of (A) Tg-control (Tg-Con) mice and (B) HJ-treated Tg-APP/PS1 (Tg-HJ) mice. Scale bar, $100 \mu \mathrm{m}$. (C) Percentage area of cortex occupied by Bam10 immunoreactivity in the vehicle-treated Tg-APP/PS1 control mice and HJ-treated Tg-APP/ PS1 mice. Photomicrographs showing anti-phospho-tau antibody (AT8)-stained cortex of (D) vehicle-treated Tg-APP/PS1 control mice and (E) HJ-treated Tg-APP/PS1 mice. Scale bar, $100 \mu \mathrm{m}$. (F) Percentage area of cortex occupied by AT8 immunoreactivity in the vehicle-treated Tg-APP/PS1 control mice and HJ-treated Tg-APP/PS1 mice. ${ }^{*}$ p $<0.05$ and ${ }^{* *} \mathrm{p}<0.01$, significant differences from Tg-control, as shown by the Student's t-test. Data are presented as the means \pm SEM.

results suggest that $\mathrm{HJ}$ has an effect on $\mathrm{A} \beta$ clearance through the increased level of IDE, but not by APP processing.

HJ attenuates neuroinflammation in the brains of $T g-A P P / P S 1$ mice. Previously, it has been reported that $\mathrm{A} \beta$ is able to initiate inflammation, which implicates the activation of microglia and the recruitment of astrocytes, and the release of cytokines, such as TNF- $\alpha$, interferon- $\gamma$, IL- $1 \beta$, IL-1 $\alpha$ and COX-2, and ROS that are involved in neuronal and synaptic damage $(4,34)$. Thus, to investigate whether $\mathrm{HJ}$ can reduce the activation of microglia and astrocytes in Tg-APP/PS1 mice, we measured the number of Iba-1 immunoreactive cells and the areas of GFAP immunoreactivity in the cortex (Fig. 6). The number of Iba-1-positive cells was significantly decreased in the cortex tissues of the HJ-treated Tg-APP/ PS1 mice (Fig. 6A-C; p<0.05). Moreover, the percentage area occupied by active astrocytes was also significantly decreased in the cortex tissues of the HJ-treated Tg-APP/ PS1 mice (Fig. 6D-F; p<0.05). Additionally, the mRNA levels of TNF- $\alpha$ and IL- 6 in the cortex homogenates in the HJ-treated Tg-APP/PS1 group were significantly lower than those in the Tg-APP/P1 control group (Fig. 7A and B; $<<0.05$ and $\mathrm{p}<0.01)$. However, the mRNA expression levels of IL- $1 \beta$ in the HJ-treated Tg-APP/PS1 group were not significantly altered (Fig. 7C). These findings indicated that the activation of microglia and astrocytes, and the expression levels of the pro-inflammatory cytokines, TNF- $\alpha$ and IL-6, were markedly reduced by treatment with $\mathrm{HJ}$ for 2.5 months in the animal model of AD. These results suggest that treatment with HJ effectively attenuates neuroinflammation in the brains of Tg-APP/PS1 mice.

\section{Discussion}

In the present study, we demonstrated that $\mathrm{HJ}$ inhibits inflammation in BV2 microglial cells. HJ significantly decreased the LPS-stimulated production of pro-inflammatory cytokines, such as TNF- $\alpha$, IL-1 $\beta$ and IL- 6 , as well as the production of the pro-inflammatory mediator, NO. HJ improved object recognition and spatial working memory in a mouse model of $\mathrm{AD}$, and reduced $\mathrm{A} \beta$ deposition and tau hyperphosphorylation in the cortex tissues of Tg-APP/PS1 mice. We found that treatment with $\mathrm{HJ}$ increased the protein expression of IDE, which is one of the degrading enzymes of $\mathrm{A} \beta$, in the cortex tissues of Tg-APP/ PS1 mice. Further, we observed that HJ has anti-inflammatory activities, such as the attenuation of the activation of microglia and astrocytes, and the decreased mRNA levels of TNF- $\alpha$ and IL-6 in the cortex tissues of HJ-treated Tg-APP/PS1 mice.

In the present study, to investigate the anti-inflammatory effects of HJ on LPS-activated BV2 microglia cells, the effects of $\mathrm{HJ}$ on the expression and production of pro-inflammatory cytokines, and the expression of iNOS and the production of 


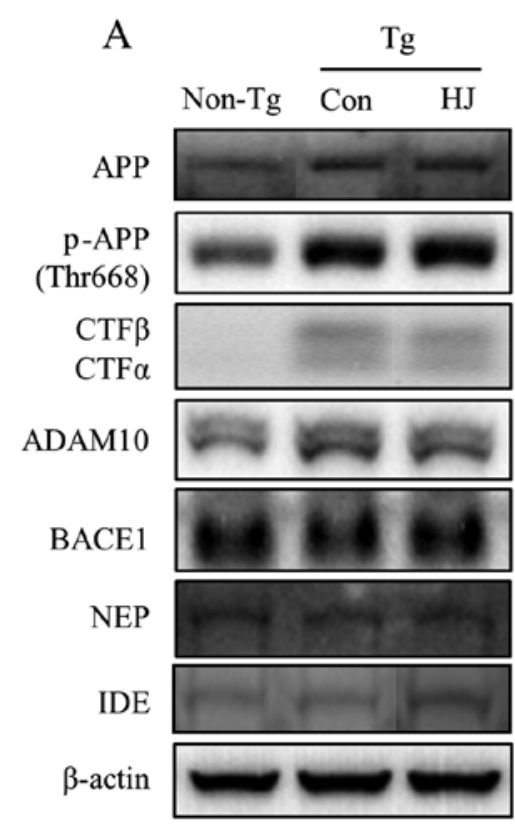

F

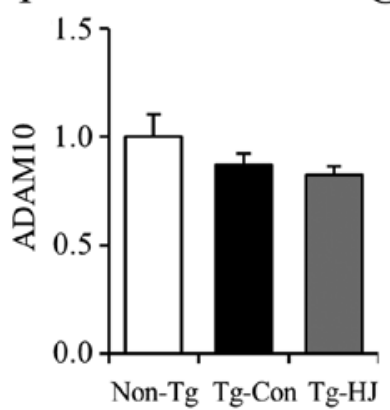

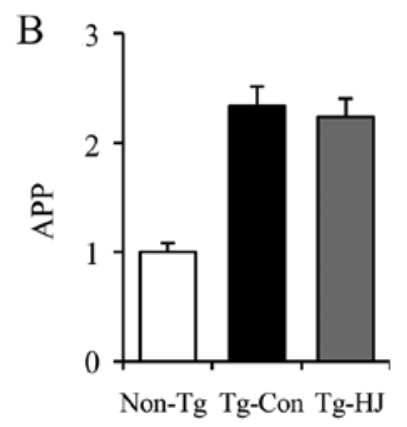

D

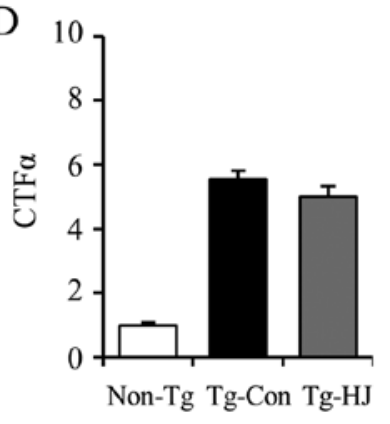

$\mathrm{H}$

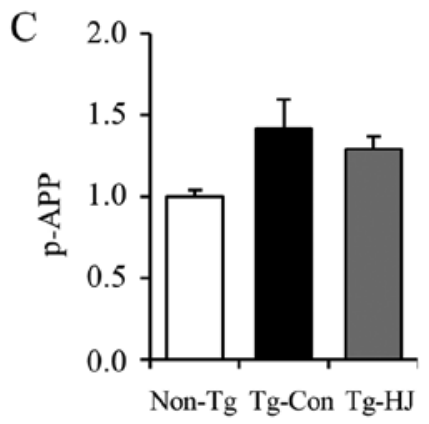

E

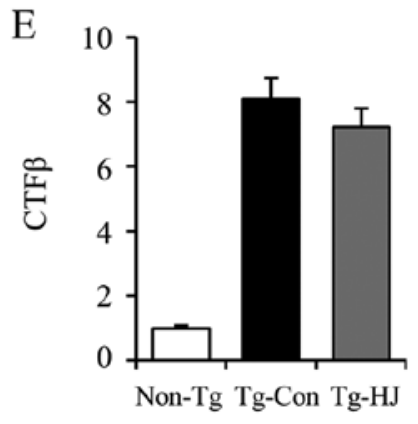

I
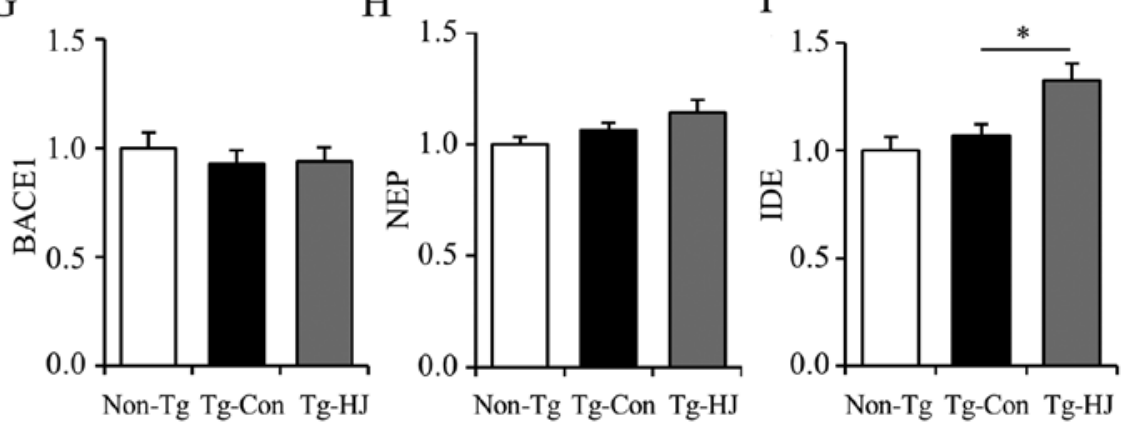

Figure 5. Effect of Humulus japonicus (HJ) on APP processing and degrading enzyme. Western blot analysis and quantitative analysis for (A-E) APP and APP metabolites and (F-I) a disintegrin and metalloproteinase 10 (ADAM10), $\beta$-site APP-cleaving enzyme 1 (BACE1), neprilysin (NEP) and insulin degrading enzyme (IDE) in the cortex homogenates of non-Tg control (Non-Tg), vehicle-treated APP/PS1 transgenic (Tg-APP/PS1) control (Tg-Con), and HJ-treated Tg-APP/PS1 (Tg-HJ) mice. " p<0.05, significant differences from Tg-control, as shown by the Student's t-test. Data are presented as the means \pm SEM.

NO were determined. The results revealed that $\mathrm{HJ}$ inhibited the LPS-induced increase in the expression of IL-1 $\beta$, IL-6, TNF- $\alpha$, and iNOS in the BV2 cells. The production of IL-1 $\beta$, IL-6, TNF- $\alpha$ and NO in the supernatant of the BV2 cells was also markedly inhibited by treatment with HJ. Furthermore, the anti-inflammatory activities of $\mathrm{HJ}$ were revealed in $\mathrm{HJ}$-treated Tg-APP/PS1 mice; the activation of microglia and astrocytes, and the mRNA expression of TNF- $\alpha$ and IL- 6 , the major cytokines in the process of AD pathogenesis, was markedly decreased in the cortex tissues of HJ-treated Tg-APP/PS1 mice. Chronic neuroinflammation induced by pro-inflammatory cytokines released from activated microglia and astrocytes has been recognized as one of the major mechanisms of AD pathophysiology (3). A $\beta$ plaques and tangles in the brains of patients with AD stimulate a chronic inflammatory reaction to clear this debris (35-37). However, chronically activated glia can contribute to neuronal dysfunction and cell death by releasing highly toxic products, such as ROS, NO and excitatory amino acids $(38,39)$. In addition, $\gamma$-aminobutyric acid released from reactive and activated astrocytes in AD can impair synaptic plasticity, and learning and memory in AD (40). A number of cytokines, including IL- $1 \alpha$, IL-1 $\beta$, IL-6, TNF- $\alpha$ and IL- 8 are increased in AD-affected d brain tissue (41). Many compounds that alleviate $\mathrm{AD}$-type pathology and cognitive deficits inhibit the expression and release of these cytokines $(15-18,36,42)$. Based on these studies, the anti-inflammatory effects of $\mathrm{HJ}$ may attenuate $\mathrm{A} \beta$ deposition, tau hyperphosphorylation, and cognitive deterioration in an animal model of AD.

$A \beta$ is known to be generated by sequential proteolysis of APP, a large integral membrane protein that is cleaved by BACE1 at first, followed by CTF $\beta$ in the membrane and by $\gamma$-secretase in the transmembrane domain $(43,44)$. The production of $\mathrm{A} \beta$ is avoided by an alternate APP cleavage pathway mediated by the $\alpha$-secretase followed by $\gamma$-secretase $(43,44)$. HJ had no effect on the expression of total APP, CTF $\alpha$, and APP cleavage form mediated by the $\alpha$-secretase and CTF $\beta$. The expression of BACE1 and ADAM10 was not altered by treatment with $\mathrm{HJ}$. These results suggest that $\mathrm{HJ}$ has no effect on APP processing in Tg-APP/PS1 mice.

The degradation and clearance of amyloid plaques, as well as alternative APP processing is an interesting therapeutic approach, and the proteases, NEP and IDE, have shown to cleave $A \beta$ (45-47). In our study, IDE protein levels in the cortex tissues of Tg-APP/PS1 mice were significantly increased 
A

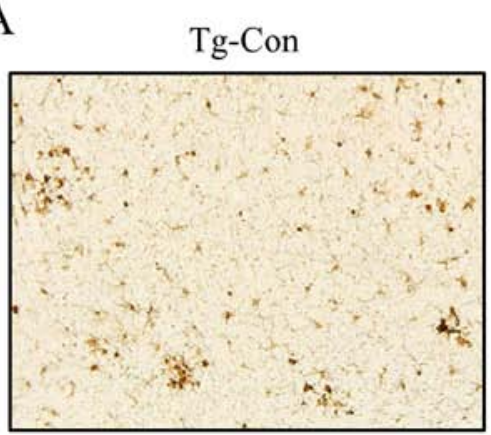

D

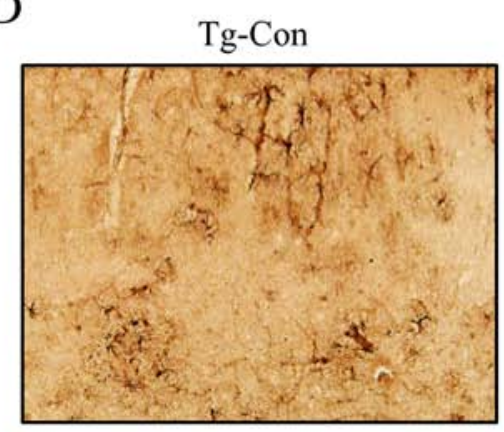

B

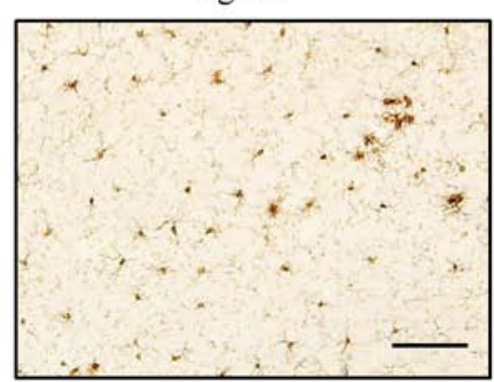

E

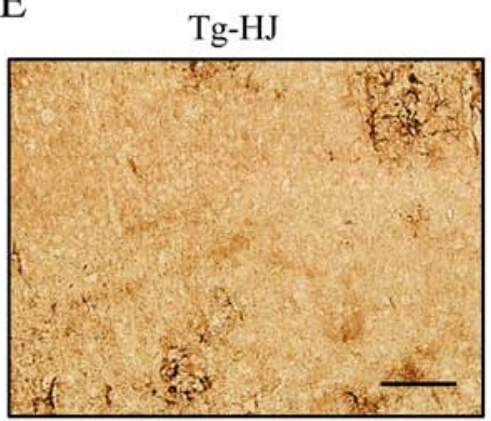

C

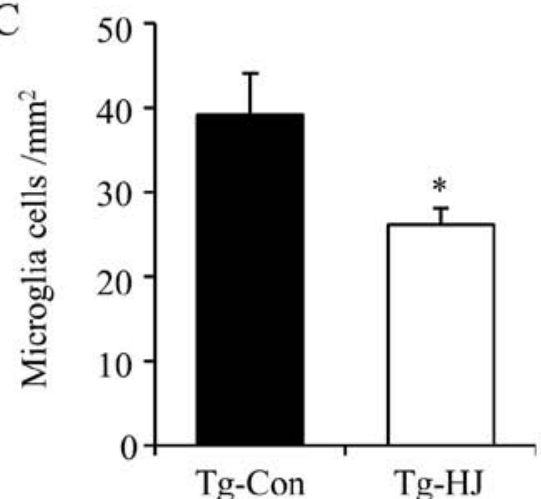

F

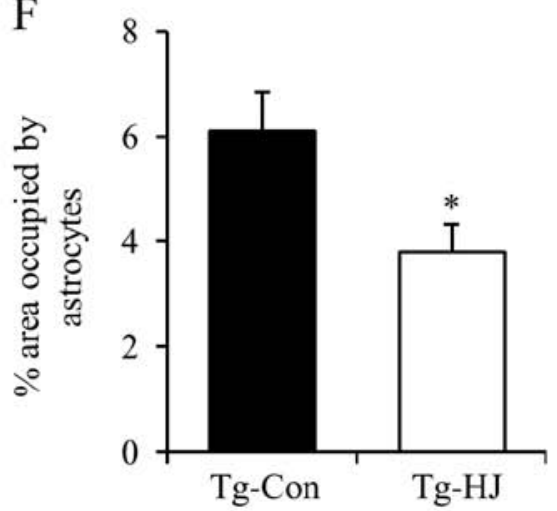

Figure 6. Effect of Humulus japonicus $(\mathrm{HJ})$ on neuroinflammation in vivo. Immunostaining and quantification of microgliosis [stained by (A-C) ionized calcium-binding adapter molecule 1 (Iba-1) antibody] and astrocytosis [(D-F) stained by glial fibrillary acidic protein (GFAP) antibody] in the cortex of vehicletreated APP/PS1 transgenic (Tg-APP/PS1) control (Tg-Con), and HJ-treated Tg-APP/PS1 (Tg-HJ) mice. Scale bar, $100 \mu \mathrm{m}$. ${ }^{*} \mathrm{p}<0.05$, significant differences from Tg-control, as shown by the Student's t-test. Data are presented as the means \pm SEM.
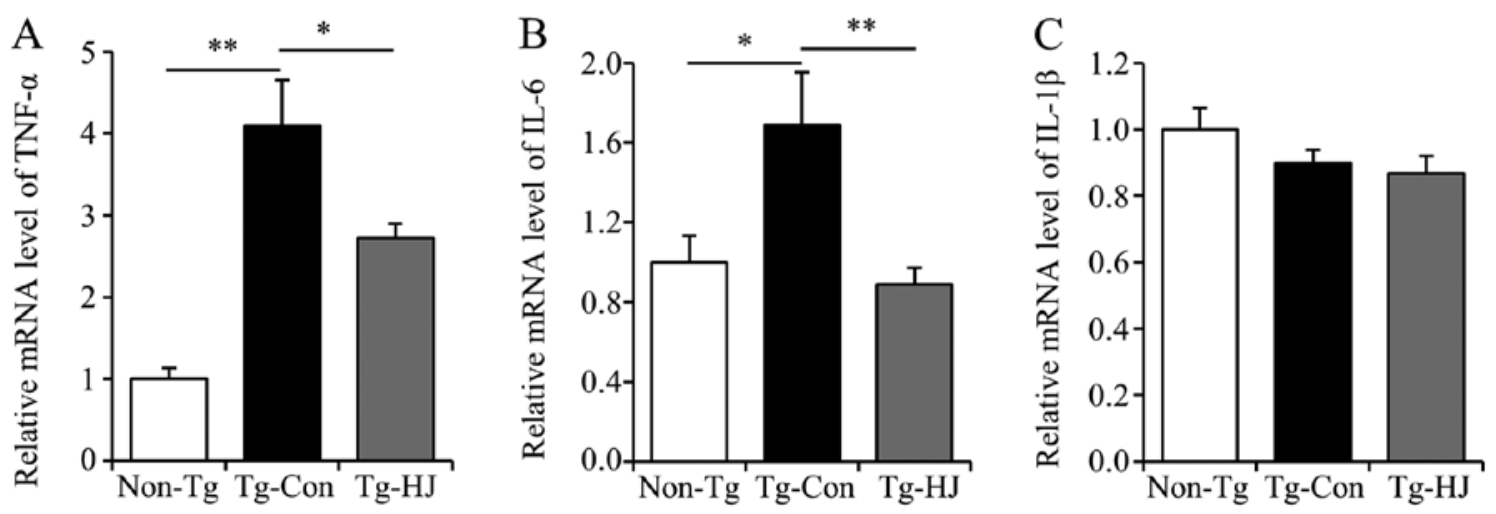

Figure 7. Effects of Humulus japonicus (HJ) on the mRNA expression of (A) tumor necrosis factor- $\alpha$ (TNF- $\alpha$ ), (B) interleukin-6 (IL-6) and (C) interleukin-1 $\beta$ (IL$1 \beta$ ) in APP/PS1 transgenic (Tg-APP/PS1) mice. RT-qPCR was performed to detect the mRNA levels of TNF- $\alpha$, IL- 6 and IL-1 $\beta$ in the cortex tissues of 7.5-month-old non-Tg control (Non-Tg), vehicle-treated Tg-APP/PS1 (Tg-Con), and HJ-treated Tg-APP/PS1 (Tg-HJ) mice. ${ }^{*} \mathrm{p}<0.05$ and ${ }^{* *} \mathrm{p}<0.01$, significant differences from the indicated group, as shown by one-way ANOVA, followed by Turkey Kramer's post hoc test. Data are presented as the means \pm SEM.

by treatment with $\mathrm{HJ}$; however, the NEP protein levels were not altered in the HJ-treated Tg-APP/PS1 mice. IDE is the main extracellular protease degrading $A \beta$ (33). The increased expression of IDE reduces the A $\beta$ level and inhibits amyloid plaque formation $(46,47)$, and the genetic inactivation of IDE in mice increases brain $A \beta$ levels (48). IDE is expressed and released by microglia and neurons $(33,47)$. A decrease in IDE levels with the concomitant upregulation of TNF- $\alpha$ and IL-1 $\beta$ was observed in 8-month-old Tg-APP/PS1 mice, and the inhibition of microglial activation by donepezil has been shown to lead to alterations in IDE levels (42). Unlike previous studies $(42,49)$, we observed that IDE expression in the cortex tissues of Tg-APP/PS1 mice was not decreased (Fig. 5), but treatment with HJ increased IDE protein levels. Therefore, it is conceivable that this increased IDE expression may enhance $\mathrm{A} \beta$ clearance.

Our in vitro and in vivo analysis with microglial cells and an animal model of AD demonstrated that HJ has strong anti- 
inflammatory properties, and attenuates $\mathrm{AD}$ pathophysiology in the CNS. The anti-inflammatory capability of HJ may contribute to its anti-microbial, anti-mycobacterial and anticancer effects $(20,21,50,51)$. Although it was not verified in this study, previous studies have shown that HJ has an antioxidant activity in vitro $(20,21,51)$. The reduction in cellular expression and activity of antioxidant proteins and the resulting increased oxidative stress can contribute to the progression of brain aging and the development of neurodegenerative diseases, including AD (52). These data suggest that this natural plant, HJ, may prove to be useful in the treatment of inflammatory diseases and several neurodegenerative diseases that are associated with microglial cell activation and oxidative stress.

\section{Acknowledgements}

This study was supported by KRIBB Research Initiative Program of the Republic of Korea. The authors would like to thank Mr. In-Bok Lee, Ms. Jung-Hyun Choi and Ms. Yun-Jeong Seo for their technical assistance.

\section{References}

1. Ali FEA, Barnham KJ, Barrow CJ and Separovic F: Metal-catalyzed oxidative damage and oligomerization of the amyloid-peptide of Alzheimer's disease. Aust J Chem 57: 511-518, 2004.

2. Baldeiras I, Santana I, Proença MT, Garrucho MH, Pascoal R, Rodrigues A, Duro D and Oliveira CR: Oxidative damage and progression to Alzheimer's disease in patients with mild cognitive impairment. J Alzheimers Dis 21: 1165-1177, 2010.

3. Zhang FJiang L. Neuroinflammation in Alzheimer's disease. Neuropsychiatr Dis Treat 11: 243-256, 2015.

4. Birch AM, Katsouri L and Sastre M: Modulation of inflammation in transgenic models of Alzheimer's disease. J Neuroinflammation 11: 25, 2014.

5. Finch CE and Morgan TE: Systemic inflammation, infection, ApoE alleles, and Alzheimer disease: a position paper. Curr Alzheimer Res 4: 185-189, 2007.

6. Frank B and Gupta S: A review of antioxidants and Alzheimer's disease. Ann Clin Psychiatry 17: 269-286, 2005.

7. Zhu X, Su B, Wang X, Smith MA and Perry G: Causes of oxidative stress in Alzheimer disease. Cell Mol Life Sci 64: 2202-2210, 2007.

8. Heneka MT and O'Banion MK: Inflammatory processes in Alzheimer's disease. J Neuroimmunol 184: 69-91, 2007.

9. El Khoury J and Luster AD: Mechanisms of microglia accumulation in Alzheimer's disease: therapeutic implications. Trends Pharmacol Sci 29: 626-632, 2008.

10. Mandrekar-Colucci S, Karlo JC and Landreth GE: Mechanisms underlying the rapid peroxisome proliferator-activated receptor- $\gamma$-mediated amyloid clearance and reversal of cognitive deficits in a murine model of Alzheimer's disease. J Neurosci 32 10117-10128, 2012.

11. Noble W, Garwood C, Stephenson J, Kinsey AM, Hanger DP and Anderton BH: Minocycline reduces the development of abnormal tau species in models of Alzheimer's disease. FASEB J 23: 739-750, 2009.

12. Sastre $M$ and Gentleman SM: NSAIDs: how they work and their prospects as therapeutics in Alzheimer's disease. Front Aging Neurosci 2: 20, 2010.

13. Seabrook TJ, Jiang L, Maier M and Lemere CA: Minocycline affects microglia activation, Abeta deposition, and behavior in APP-tg mice. Glia 53: 776-782, 2006.

14. Tweedie D, Ferguson RA, Fishman K, Frankola KA, Van Praag H, Holloway HW, Luo W, Li Y, Caracciolo L, Russo I, et al: Tumor necrosis factor- $\alpha$ synthesis inhibitor 3,6'-dithiothalidomide attenuates markers of inflammation, Alzheimer pathology and behavioral deficits in animal models of neuroinflammation and Alzheimer's disease. J Neuroinflammation 9: 106, 2012.

15. Chan MM, Huang HI, Fenton MR and Fong D: In vivo inhibition of nitric oxide synthase gene expression by curcumin, a cancer preventive natural product with anti-inflammatory properties. Biochem Pharmacol 55: 1955-1962, 1998.
16. Wang J, Ho L, Zhao W, Ono K, Rosensweig C, Chen L, Humala N, Teplow DB and Pasinetti GM: Grape-derived polyphenolics prevent Abeta oligomerization and attenuate cognitive deterioration in a mouse model of Alzheimer's disease. J Neurosci 28 : 6388-6392, 2008.

17. Xia EQ, Deng GF, Guo YJ and Li HB: Biological activities of polyphenols from grapes. Int J Mol Sci 11: 622-646, 2010.

18. Yang F, Lim GP, Begum AN, Ubeda OJ, Simmons MR, Ambegaokar SS, Chen PP, Kayed R, Glabe CG, Frautschy SA and Cole GM: Curcumin inhibits formation of amyloid beta oligomers and fibrils, binds plaques, and reduces amyloid in vivo. J Biol Chem 280: 5892-5901, 2005.

19. Jeong KY, Han IS, Choi SY, Lee JH, Lee JS, Hong CS and Park JW: Allergenicity of recombinant profilins from Japanese hop, Humulus japonicus. J Investig Allergol Clin Immunol 23: 345-350, 2013.

20. Lee YR, Kim KY, Lee SH, Kim MY, Park HJ and Jeong HS: Antioxidant and antitumor activities of methanolic extracts from Humulus japonicus. Korean J Food Nutr 25: 357-361, 2012.

21. Park SW, Woo CJ, Chung SK and Chung KT: Antimicrobial and antioxidative activities of solvent fraction from Humulus japonicus. Korean J Food Sci Technol 26: 464-470, 1994.

22. Hwang SY, Jo MJ, Kim SC and Jee SY: Anti-inflammaory effects of the MeOH extract of Humulus japonicus in vivo. J Korean Orient Med Ophthalmol Otolaryngol Derm 22: 92-103, 2009.

23. Jankowsky JL, Fadale DJ, Anderson J, Xu GM, Gonzales V, Jenkins NA, Copeland NG, Lee MK, Younkin LH, Wagner SL, et al: Mutant presenilins specifically elevate the levels of the 42 residue beta-amyloid peptide in vivo: evidence for augmentation of a 42-specific gamma secretase. Hum Mol Genet 13: 159-170, 2004.

24. Jankowsky JL, Slunt HH, Ratovitski T, Jenkins NA, Copeland NG and Borchelt DR: Co-expression of multiple transgenes in mouse CNS: a comparison of strategies. Biomol Eng 17: 157-165, 2001.

25. Park HY, Kang YM, Kang Y, Park TS, Ryu YK, Hwang JH, Kim YH, Chung BH, Nam KH, Kim MR, et al: Inhibition of adenylyl cyclase type 5 prevents L-DOPA-induced dyskinesia in an animal model of Parkinson's disease. J Neurosci 34: 11744-11753, 2014.

26. Akkerman S, Blokland A, Reneerkens O, van Goethem NP, Bollen E, Gijselaers HJ, Lieben CK, Steinbusch HW and Prickaerts J: Object recognition testing: methodological considerations on exploration and discrimination measures. Behav Brain Res 232: 335-347, 2012.

27. Antunes M and Biala G: The novel object recognition memory: neurobiology, test procedure, and its modifications. Cogn Process 13: 93-110, 2012

28. Wasilewska-Sampaio AP, Santos TG, Lopes MH, Cammarota M and Martins VR: The growth of glioblastoma orthotopic xenografts in nude mice is directly correlated with impaired object recognition memory. Physiol Behav 123: 55-61, 2014.

29. Belforte JE, Zsiros V, Sklar ER, Jiang Z, Yu G, Li Y, Quinlan EM and Nakazawa K: Postnatal NMDA receptor ablation in corticolimbic interneurons confers schizophrenia-like phenotypes. Nat Neurosci 13: 76-83, 2010.

30. Kim KS, Kang YM, Kang Y, Park TS, Park HY, Kim YJ, Han BS, $\mathrm{Kim} \mathrm{CH}$, Lee $\mathrm{CH}$, Ardayfio PA, et al: Pitx3 deficient mice as a genetic animal model of co-morbid depressive disorder and parkinsonism. Brain Res 1552: 72-81, 2014.

31. Sierksma AS, Prickaerts J, Chouliaras L, Rostamian S, Delbroek L, Rutten BP, Steinbusch HW and van den Hove DL: Behavioral and neurobiological effects of prenatal stress exposure in male and female APPswe/PS1dE9 mice. Neurobiol Aging 34: 319-337, 2013.

32. Hafez D, Huang JY, Huynh AM, Valtierra S, Rockenstein E, Bruno AM, Lu B, DesGroseillers L, Masliah E and Marr RA: Neprilysin-2 is an important $\beta$-amyloid degrading enzyme. Am J Pathol 178: 306-312, 2011

33. Qiu WQ, Walsh DM, Ye Z, Vekrellis K, Zhang J, Podlisny MB, Rosner MR, Safavi A, Hersh LB and Selkoe DJ: Insulin-degrading enzyme regulates extracellular levels of amyloid beta-protein by degradation. J Biol Chem 273: 32730-32738, 1998.

34. Sastre M, Klockgether T and Heneka MT: Contribution of inflammatory processes to Alzheimer's disease: molecular mechanisms. Int J Dev Neurosci 24: 167-176, 2006.

35. McGeer PL and McGeer EG: The inflammatory response system of brain: implications for therapy of Alzheimer and other neurodegenerative diseases. Brain Res Brain Res Rev 21: 195-218, 1995. 
36. Rubio-Perez JM and Morillas-Ruiz JM. A review: inflammatory process in Alzheimer's disease, role of cytokines. ScientificWord Journal 2012: 756357, 2012.

37. Town T,Nikolic V and Tan J: The microglial 'activation' continuum: from innate to adaptive responses. J Neuroinflammation 2: 24, 2005.

38. Brown GC and Bal-Price A: Inflammatory neurodegeneration mediated by nitric oxide, glutamate, and mitochondria. Mol Neurobiol 27: 325-355, 2003.

39. Halliday G, Robinson SR, Shepherd C and Kril J: Alzheimer's disease and inflammation: a review of cellular and therapeutic mechanisms. Clin Exp Pharmacol Physiol 27: 1-8, 2000.

40. Jo S, Yarishkin O, Hwang YJ, Chun YE, Park M, Woo DH, Bae JY, Kim T, Lee J, Chun H, et al: GABA from reactive astrocytes impairs memory in mouse models of Alzheimer's disease. Nat Med 20: 886-896, 2014.

41. Akiyama H, Barger S, Barnum S, Bradt B, Bauer J, Cole GM, Cooper NR, Eikelenboom P, Emmerling M, Fiebich BL, et al: Inflammation and Alzheimer's disease. Neurobiol Aging 21: $383-421,2000$

42. Guo HB, Cheng YF, Wu JG, Wang CM, Wang HT, Zhang C, Qiu ZK and Xu JP: Donepezil improves learning and memory deficits in APP/PS1 mice by inhibition of microglial activation. Neuroscience 290: 530-542, 2015.

43. Edbauer D, Winkler E, Regula JT, Pesold B, Steiner H and Haass C: Reconstitution of gamma-secretase activity. Nat Cell Biol 5: 486-488, 2003.

44. Vassar R, Bennett BD, Babu-Khan S, Kahn S, Mendiaz EA, Denis P, Teplow DB, Ross S, Amarante P, Loeloff R, et al Beta-secretase cleavage of Alzheimer's amyloid precursor protein by the transmembrane aspartic protease BACE. Science 286: 735-741, 1999.

45. Iwata N, Tsubuki S, Takaki Y, Watanabe K, Sekiguchi M, Hosoki E, Kawashima-Morishima M, Lee HJ, Hama E, Sekine-Aizawa Y and Saido TC: Identification of the major Abeta1-42-degrading catabolic pathway in brain parenchyma: suppression leads to biochemical and pathological deposition. Nat Med 6: 143-150, 2000.
46. Leissring MA, Farris W, Chang AY, Walsh DM, Wu X, Sun X, Frosch MP and Selkoe DJ: Enhanced proteolysis of beta-amyloid in APP transgenic mice prevents plaque formation, secondary pathology, and premature death. Neuron 40: 1087-1093, 2003.

47. Vekrellis K, Ye Z, Qiu WQ, Walsh D, Hartley D, Chesneau V, Rosner MR and Selkoe DJ: Neurons regulate extracellular levels of amyloid beta-protein via proteolysis by insulin-degrading enzyme. J Neurosci 20: 1657-1665, 2000.

48. Leal MC, Dorfman VB, Gamba AF, Frangione B, Wisniewski T, Castaño EM, Sigurdsson EM and Morelli L: Plaque-associated overexpression of insulin-degrading enzyme in the cerebral cortex of aged transgenic tg2576 mice with Alzheimer pathology. J Neuropathol Exp Neurol 65: 976-987, 2006.

49. Cook DG, Leverenz JB, McMillan PJ, Kulstad JJ, Ericksen S, Roth RA, Schellenberg GD, Jin LW, Kovacina KS and Craft S: Reduced hippocampal insulin-degrading enzyme in late-onset Alzheimer's disease is associated with the apolipoprotein E-epsilon4 allele. Am J Pathol 162: 313-319, 2003.

50. Hong MS, Son ES, Lee SJ, Lee SK, Lee YJ, Song SD, Cho SN, Barry CEIII and Eum SY: Anti-mycobacterial Effects of the Extract of Humulus japonicas. Korean J Food Sci Technol 46: 94-99, 2014.

51. Park SW, Kim SH and Chung SK: Antimutagenic effects and isolation of flavonoids from HJ extract. Korean J Food Sci Technol 27: 897-901, 1995.

52. Di Bona D, Scapagnini G, Candore G, Castiglia L, Colonna-Romano G, Duro G, Nuzzo D, Iemolo F, Lio D, Pellicanò $\mathrm{M}$, et al: Immune-inflammatory responses and oxidative stress in Alzheimer's disease: therapeutic implications. Curr Pharm Des 16: 684-691, 2010. 